\title{
First Record of Cacopsylla pulchella (Hemiptera, Psyllidae) in Croatia
}

\author{
Milan Pernek ${ }^{1}$, Marta Matek ${ }^{1 *}$, Tamara Maretić2 Nikola Lacković $^{3}$, Dinka Matošević ${ }^{1}$
}

(1) Croatian Forest Research Institute, Division for Forest Protection and Game Management, Cvjetno naselje 41, HR-10450 Jastrebarsko, Croatia; (2) KTD Ivanj d.o.o.,Trg Vinodolskog zakona 5, HR-51250 Novi Vinodolski, Croatia; (3) Arbofield, Antuna Mihanovića 3, HR-10450 Jastrebarsko, Croatia

* Correspondence: e-mail: martam@sumins.hr
Citation: Pernek M, Matek M, Matošević D, Maretić T, Lacković N, 2020. First Record of Cacopsylla pulchella Low 1877 (Hemiptera, Psyllidae) in Croatia. South-east Eur for 11(1): 91-94. https://doi.org/10.15177/ seefor.20-10.

Received: 19 May 2020; Revised: 14 Jun 2020; Accepted: 16 Jun 2020; Published online: 24 Jun 2020

\begin{abstract}
The aim of this study is to identify plant lice Cacopsylla pulchella a new alien insect in the fauna of Croatia. We propose a new method of infestation level assessment in order to assess the potential of this insect as a pest. In May 2020 samples were collected from eleven locations in Croatia, where Cercis siliquastrum is grown in parks. Adults and nymphs of $C$. pulchella were collected together with a plant material and brought to entomological laboratory for further analysis. Field research was performed in order to assess the distribution and infestation intensity across various localities in Croatia. The intensity of infestation was assessed heuristically by visual examination and was categorized in four categories: 0 ) no infestation, 1) low, 2) moderate and 3) high infestation. C. pulchella was confirmed on C. siliquastrum in eleven localities in Croatia. Most of the infested trees had a low or moderate intensity of infestation. Damages caused by this insect are due to the emission of honey dew, a small spherical drop covered with waxy secretion causing necrotic areas which could lead to the premature fall of the leaves. It is not known what kind of progress in infestation intensity could be expected so infested trees found in this study should be checked closely in the coming years. It is strongly suggested to continue the monitoring of this alien insect on C. siliquastrum in Croatia and to estimate its potential of become an invasive pest which could endanger ornamental and other values of its hosts.
\end{abstract}

Keywords: alien pest; Cercis siliquastrum; Judas tree; damage, infestation level

\section{INTRODUCTION}

Insects have been documented as a successful invaders and one of the most important alien invasive species group, in term of numbers as well as in impact (Brockerhoff and Liebhold 2017). In Europe more than 400 alien invasive insect species feeding on woody plants have been identified (Roques et al. 2016), with new species constantly introduced with no signs of saturation (Seebens et al. 2017). In Croatia 101 species of insect and mite alien species on woody plants have been recorded until 2013 (Matošević and Pajač 2013) with constant influx of new species in the following years (Matošević unpublished data). Members of all insect orders have been introduced and established in Europe, mainly from Asia and Northern America but also Mediterranean species have been spreading northwards and invading new habitats and making damages (Matošević and Pajač 2013, Roques et al. 2015). Until now only one alien species from the family of Psyllidae (Hemiptera) has been recorded in Croatia (Acizzia jamatonica Kuwayama 1908) (Seljak et al. 2004, Seljak 2006).

Cacopsylla pulchella Low (Hemiptera, Psyllidae) is a jumping plant-lice that is considered as an alien species in Europe (Mifsud et al. 2010). It is probably native in Eastern Mediterranean basin and Asia Minor (Mifsud et al. 2010). The first confirmed record of C. pulchella in Europe dates to 1964 in France (Hodkinson and White 1979) and afterwards in many European countries, such as: Austria, France, Great Britain, Greece, Swizerland (ZeidanGèze and Burckhardt 1998), Germany, Italy, Ukraine (Burckhardt 2010), Spain, Portugal (Sánchez 2011), Slovenia (Seljak 2006), Hungary (Ripka 2008), Serbia (Jerinić-Prodanović 2011) and Russia (Balakhnina et al. 2015). It was found also in Israel (Spodek et al. 2017) and Lebanon (Zeidan-Gèze and Burckhardt 1998). As a monophagous species it is feeding on the Judas tree Cercis siliquastrum L. (Burckhardt 1999), but has been also found on C. canadensis L. (Balakhnina et al. 2015). Judas tree is valued ornamental plant in the Mediterranean regions of Croatia. Attacks of $C$. pulchella reduce the ornamental value of the trees causing chlorosis and wilting of leaves (Rapisarda and Belcari 1997). The nymphs produce sugary honeydew which contaminates everything under the tree and is a nuisance to inhabitants.

The aim of this research is first record of the psyllid $C$. pulchella as a new addition to the alien insect fauna of Croatia and assessment of its potential as a pest causing damages on trees. 


\section{MATERIALS AND METHODS}

In May 2020 samples were collected from eleven locations in Croatia, mostly in the Mediterranean part, where C. siliquastrum is grown in parks. In the continental part trees were checked in Zagreb. Adults and nymphs of $C$. pulchella were collected together with a plant material and brought to the entomological laboratory in Croatian Forest Research Institute for further analysis. They were identified according to the keys by Hodkinson and White (1979), Loginova (1964) and Burckhardt (1999). Images of infested leaves and branches were taken with Olympus E-30 camera and detailed images of adults and nymphs were taken under dissecting microscope (Olympus, model SZX7) with an Olympus XC30 camera. All samples are kept in Croatian Forest Research Institute.

Additional field research was performed in order to assess the distribution and infestation intensity across various localities in Croatia (Table 1). The intensity of infestation was assessed heuristically by visual examination and was categorized in four categories: 0) no symptoms visible from distance or when observing single leaves, 1) low - symptoms are not visible when looking at a whole tree, only few specimens can be detected sporadically on single leaves, 2) moderate-symptoms are barely visible when looking at a whole tree, more than 5 specimens can be counted on $50 \%$ of observed leaves; 3 ) high - symptoms are visible when looking at a whole tree from distance, more than 10 specimens can be counted on at least $50 \%$ of observed leaves.

\section{RESULTS AND DISCUSSION}

This is the first record of C. pulchella in Croatia. Its presence was confirmed in all inspected localities (Table 1). Most of the trees $(80 \%)$ had a low or moderate intensity of infestation (Table 1). However, the highest infestation level was recorded in Novi Vinodolski and Pula. Introduction pathway of C. pulchella to Croatia is unknown and these first records (in Mediterranean and continental Croatia) may be independent from each other. It is possible that $C$. pulchella has been present in Croatia for several years or longer but has been overlooked due to different sampling efforts than in neighbouring countries and interests of the collectors. Wide distribution and intensity of infestation along the Croatian coast (Table 1) indicates this overlooked presence in Croatia.

Damages caused by this insect are due to the emission of honey dew, a small spherical drops covered with waxy secretion (Rapisarda and Belcari 1997). These drops cause a necrotic areas as a consequence that lead sometimes to the premature fall of the leaves. It is not known what kind of progress in infestation intensity could be expected so infested trees found in this study should be checked closely in coming years.

Adults of $C$. pulchella are olive-drab or brownish green with orange stripes on the thorax. The abdomen is dark brown and the intersegmental membranes are orange-red. On the forewings black-brown spots could be found. The genital plates of males are almost straight black colored, while females lower genital plates are yellow, long as the previous three segments and sharpened at the end, the upper genital plate is brown or dark brown, not smaller as the lower (Figure $1 \mathrm{a}$ and $1 \mathrm{~b}$ ). Nymphs have a five stages of development, the first are yellow with red eyes which are very active, while the following instars are green, settle more or less without much moving on leaves and suck the sup (Figure 1c-1d).

As $C$. siliquastrum is often planted as ornamental solitary tree or in alleys in Mediterranean parts of Croatia. C. pulchella could pose a threat to ornamental values of these trees as well as a nuisance to inhabitants due to high amount of honey dew it secrets. It has been documented that species from the genus
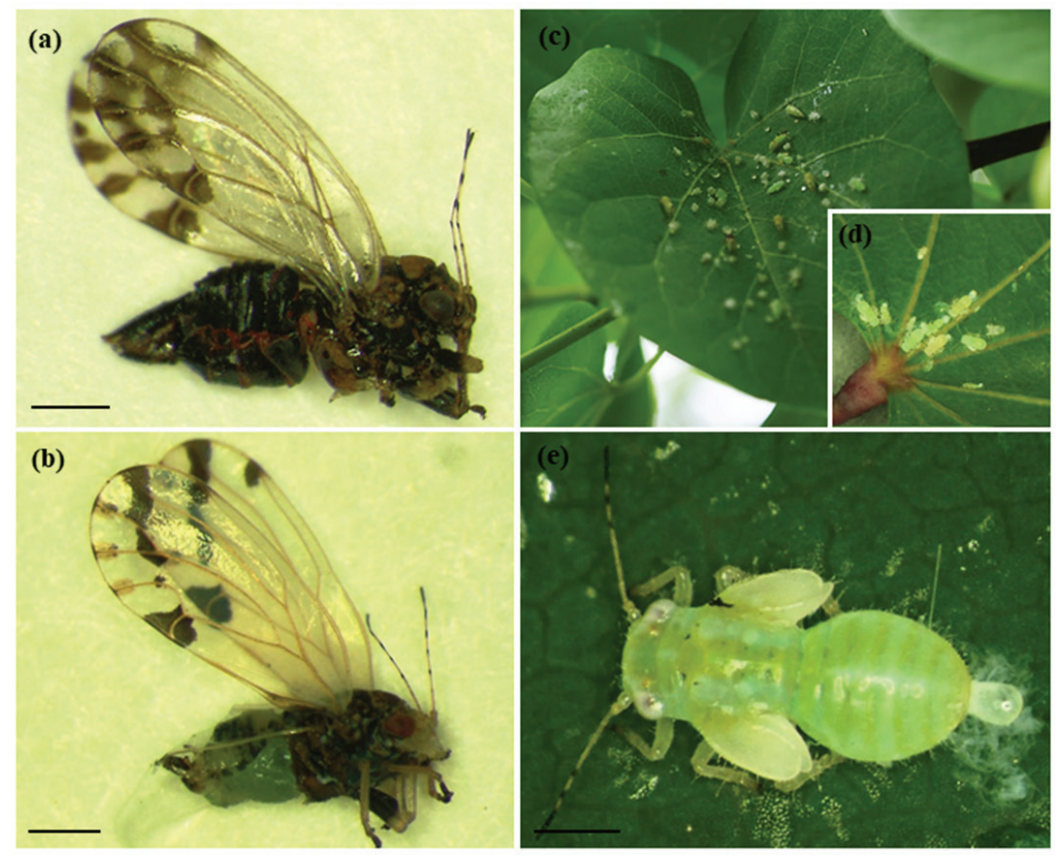

Figure 1. Cacopsylla pulchella: (a) female; (b) male; (c) developing stages on the topside of Judas tree leaf; (d) nymphs on the underside of Judas tree leaf; (e) nymph. Scale bars for (a), (b), (e) = $0.5 \mathrm{~mm}$ ). 
Table 1. Locality, address, geographic coordinates, host, number of checked trees and intensity of infestation.

\begin{tabular}{|c|c|c|c|c|}
\hline Locality & Address & $\begin{array}{l}\text { Coordinates } \\
(\varphi, \lambda)\end{array}$ & $\begin{array}{c}\text { Number of } \\
\text { checked trees }\end{array}$ & $\begin{array}{l}\text { Intensity of infestation } \\
\text { in percentage }\end{array}$ \\
\hline \multirow{3}{*}{ NOVI VINODOLSKI } & Ogulinska street & $45.122664 ; 14.802134$ & 49 & $\begin{array}{ll}1- & 18 \% \\
2- & 72 \% \\
3- & 10 \%\end{array}$ \\
\hline & Parking school & $45.127012 ; 14.791188$ & 15 & $\begin{array}{ll}1- & 7 \% \\
2- & 13 \% \\
3- & 80 \%\end{array}$ \\
\hline & Parking bus station & $45.125713 ; 14.790959$ & 4 & $\begin{array}{ll}1- & 0 \% \\
2- & 25 \% \\
3- & 75 \% \\
\end{array}$ \\
\hline CRIKVENICA & Hrusta & $45.169266 ; 14.705309$ & 5 & $\begin{array}{ll}1- & 20 \% \\
2- & 80 \% \\
3- & 0 \% \\
\end{array}$ \\
\hline \multirow{3}{*}{ KOSTRENA } & Sports hall & $45.306444 ; 14.494731$ & 6 & $\begin{array}{ll}1- & 17 \% \\
2- & 67 \% \\
3- & 17 \%\end{array}$ \\
\hline & $\begin{array}{l}\text { "Nursery" by the graveyard St. } \\
\text { Lucija }\end{array}$ & $\begin{array}{l}45.3081855 \\
14.4996189\end{array}$ & 18 & $\begin{array}{ll}1- & 6 \% \\
2- & 83 \% \\
3- & 11 \%\end{array}$ \\
\hline & Graveyard Sv. Barbara & $\begin{array}{l}45.2909732 \\
14.5368178\end{array}$ & 2 & $\begin{array}{ll}1- & 100 \% \\
2- & 0 \% \\
3- & 0 \% \\
\end{array}$ \\
\hline \multirow[b]{2}{*}{ OMIŠALJ } & Kindergarden & $45.211085 ; 14.559474$ & 1 & $0-\quad 100 \%$ \\
\hline & Park & $45.211217 ; 14.557224$ & 3 & $\begin{array}{ll}1- & 67 \% \\
2- & 33 \% \\
3- & 0 \% \\
\end{array}$ \\
\hline NJIVICE & Creska street & $45.157090 ; 14.791188$ & 1 & $\begin{array}{ll}1- & 0 \% \\
2- & 100 \% \\
3- & 0 \% \\
\end{array}$ \\
\hline \multirow{2}{*}{ VIŠKOVO } & Private garden center & $\begin{array}{l}45.3846141 \\
14.3856575\end{array}$ & 1 & $0-\quad 100 \%$ \\
\hline & Childrens playground & $\begin{array}{l}45.3794035 \\
14.3849551\end{array}$ & 11 & $\begin{array}{ll}1- & 91 \% \\
2- & 9 \% \\
3- & 0 \% \\
\end{array}$ \\
\hline OPATIJA & Park Angelina & $\begin{array}{l}45.336511 \\
14.308946\end{array}$ & 1 & $\begin{array}{ll}1- & 100 \% \\
2- & 0 \% \\
3- & 0 \% \\
\end{array}$ \\
\hline PULA & Flanatička street & $\begin{array}{l}44.8673611 ; \\
13.8498780\end{array}$ & 10 & $\begin{array}{ll}1- & 0 \% \\
2- & 20 \% \\
3- & 80 \% \\
\end{array}$ \\
\hline TRIBALJ & Treealley & $\begin{array}{l}\text { 45.222870; } \\
14.677139\end{array}$ & 21 & $\begin{array}{ll}1- & 90 \% \\
2- & 10 \% \\
3- & 0 \% \\
\end{array}$ \\
\hline BRIBIR & Park Hrvatskih branitelja - Vrba & $45.161911 ; 14.760971$ & 1 & $\begin{array}{ll}1- & 100 \% \\
2- & 0 \% \\
3- & 0 \% \\
\end{array}$ \\
\hline \multirow{2}{*}{ ZAGREB } & Botanical garden & $\begin{array}{l}45.80463 \\
15.96992\end{array}$ & 6 & $\begin{array}{ll}1- & 83 \% \\
2- & 17 \% \\
3- & 0 \%\end{array}$ \\
\hline & Bundek & $\begin{array}{l}45.78720 \\
15.98421\end{array}$ & 3 & $\begin{array}{ll}1- & 100 \% \\
2- & 0 \% \\
3- & 0 \% \\
\end{array}$ \\
\hline
\end{tabular}

Cacopshylla are carriers of phytoplasma disease (Carraro et al. 1998) but the spread of the diseases transmitted by C. pulchella as a vector is still to be studied (Laviña et al. 2004). Phytoplasmas are important insect-transmitted pathogens that cause more than 700 plant diseases, and some of them are lethal (Weintraub and Beanland 2006). It is not known whether or to which extent C. pulchella functions as a vector of diseases. Introduction pathway of $C$. pulchella to Croatia is unknown and these first records (in Mediterranean and continental Croatia) may be independent from each other. It is strongly suggested to continue the monitoring of this alien insect on Judas trees in Croatia and to estimate its potential of becoming an invasive pest (Lockwood et al. 2007) that could endanger ornamental and other values of its hosts. 


\section{Author Contributions}

MP conceived and designed the research, MM, TM and NL carried out the field measurements, MM performed laboratory analysis, MM and NL processed the data and, MP supervised the research and helped to draft the manuscript. MP, MM, DM and NL wrote the manuscript.

\section{Funding}

No funding.

\section{Acknowledgments}

We wish to thank Dr Vanja Stamenković, Botanical garden Zagreb, for his kind support in sampling of insects.

\section{Conflicts of Interest}

The authors declare no conflict of interest.

\section{REFERENCES}

Balakhnina IV, Labina ES, Gnezdilov VM, Pastarnak, 2015. First Record of the Psyllid (Löw, 1877) (Hemiptera, Psyllidae) from Krasnodar Territory. Entomological Review 95(5): 612-614. https://doi.org/10.1134/S0013873815050061.

Brockerhoff EG, Liebhold AM, 2017. Ecology of forest insect invasions. Biol Invasions 19: 3141-3159. https://doi. org/10.1007/s10530-017-1514-1.

Burckhardt D, 1999. Cacopsylla pulchella (Löw), eine Blattflohart des Judasbaums, auch in Basel (Hemiptera, Psylloidea). Mitt Entomol Ges Basel 49(2): 71-76.

Burckhardt D, 2010. Fauna Europaea Hemiptera: Psylloidea Version 2.3., http://www.faunaeur.org.

Carraro L, Osler R, Loi N, Ermacora P, Refatti E, 1998. Transmission of European stone fruit yellows phytoplasma by Cacopsylla pruni. J Plant Pathol 80: 233-239.

Hodkinson ID, White IM, 1979. Handbooks for the Identification of British Insects. Royal Entomological Society of London, London, UK, 2(5a): 1-98.

Jerinić-Prodanović D, 2011. First record of Cacopsylla pulchella (Löw, 1877) (Hemiptera: Psyllidae) in Serbia. Acta Entomol Serb 16(1-2): 139-142.

Laviña A, Sabaté J, García-Chapa M, Batlle A, Torres E, 2004. Occurrence and epidemiology of European stone fruit yellows phytoplasma in Spain. Acta Hortic 657: 489-494. https://doi. org/10.17660/ActaHortic.2004.657.79.

Loginova MM, 1964. Classification of suborder Psyllinea - Psyllids or jumping plant-lice. Opredelitel nasekomih evropejskoj chasti SSSR, I, v pjati tomah. Nauka, Moskva- Leningrad, Russia, pp. 437-482

Lockwood JL, Hoopes MF, Marchetti MP, 2007. Invasion Ecology. Blackwell Publishing, Oxford, UK.

Matošević D, Pajač Živković I, 2013. Strane fitofagne vrste kukaca i grinja na drvenastom bilju u Hrvatskoj. Sumar list 137(3-4): 191-205.

Mifsud D, Cocquempot C, Mühlethaler R, Wilson M, Streito JC, 2010. Other Hemiptera Sternorrhyncha (Aleyrodidae, Phylloxeroidea, and Psylloidea) and Hemiptera Auchenorrhyncha. Chapter 9.4. In: Roques A et al. (eds) Alien terrestrial arthropods of Europe. BioRisk 4(1): 511-552. https://doi.org/ 10.3897/biorisk.4.63.
Rapisarda C, Belcari A, 1997. Notes on some Psyllids (Homoptera: Psylloidea) infesting urban trees in Italy. Acta Hortic 496: 155164. https://doi.org/10.17660/actahortic.1999.496.19.

Ripka G, 2008. Check list of the Psylloidea of Hungary (Hemiptera: Sternorrhyncha). Acta Phytopathol Hun 41(1): 121-142. https://doi.org/10.1556/APhyt.43.2008.1.14.

Roques $A$, Auger-Rozenberg $M$, Blackburn TM et al., 2016. Temporal and interspecific variation in rates of spread for insect species invading Europe during the last 200 years. Biol Invasions 18: 907-920. https://doi.org/10.1007/s10530-0161080-y.

Roques A, Rousselet J, Avcı M, Avtzis DN, Basso A, Battisti A et al., 2015. Climate warming and past and present distribution of the processionary moths (Thaumetopoea spp.) in Europe, Asia Minor and North Africa. In: Roques A (ed) Processionary Moths and Climate Change: An Update. Springer, Dordrecht, Netherlands, pp. 81-161. https://doi.org/10.1007/978-94017-9340-7 3 .

Sánchez I, 2011. Two exotic jumping plant-lice (Hemiptera: Psylloidea) new to mainland Portugal. Boletín de la Sociedad Entomológica Aragonesa 49: 324-324.

Seebens H, Blackburn T, Dyer E et al., 2017. No saturation in the accumulation of alien species worldwide. Nat Commun 8: 14435. https://doi.org/10.1038/ncomms14435.

Seljak G, Šimala M, Stigter H, 2004. Three new non-European psyllids (Hemiptera, Psyllidae) in Slovenia and Croatia. Abstracts of the third European Hempitera Congress, St. Petersburg, Russia, pp. 66-67.

Seljak G, 2006. An overview of the current knowledge of jumping plant-lice of Slovenia (Hemiptera: Psylloidea). Acta Entomol Sloven 14(1): 11-34.

Spodek M, Burckhardt D, Freidberg A, 2017. The Psylloidea (Hemiptera) of Israel. Zootaxa 4276(3): 301-345. http:// dx.doi.org/10.11646/zootaxa.4276.3.1.

Weintraub PG, Beanland L, 2006. Insect vectors of phytoplasmas. Annu Rev Entomol 51: 91-111. https://doi.org/10.1146/ annurev.ento.51.110104.151039.

Zeidan-Gèze N, Burckhardt D, 1998. The jumping plant-lice of Lebanon (Hemiptera: Psylloidea). Rev Suisse Zool 105(4): 797812. 